\section{Somatic Growth Features of Moderate-Late and Early Preterm Infants at Early Childhood}

\author{
Erken Çocukluk Döneminde Orta ve Geç Prematüre \\ Bebeklerin Somatik Büyüme Özelliklerinin Erken \\ Prematüre Bebeklerle Karşılaştırılması
}

\section{Selahattin Akar $\odot$ Sultan Kavuncuoğlu $\odot$ Mustafa Ali Akın ๑ Esin Aldemir $\odot$ Ali Demirhan $\odot$}

\section{ABSTRACT}

Objective: The aim of this study was to compare the physical growth features of preterms infants at early childhood and to evaluate the perinatal and postnatal risk factors that affect growth.

Method: Somatic growth features including weight, height, and target height, of moderate-late and early preterm infants followed-up in our unit were evaluated at a mean age of 42 months. The effects of intrauterine growth characteristics (IUGC) on current growth as well as the effects of perinatal and early neonatal problems were investigated.

Results: A total of 232 moderate-late preterm infants (Group I) (mean gestational age [GA]: 34.9 \pm 1.2

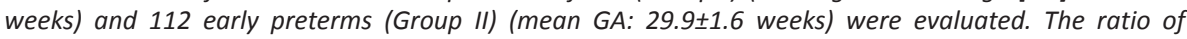
retardation in height was $2.6 \%$ and $6.3 \%$ in Group I and Group II, respectively. The rate of failure in achieving the target height was higher in Group II (3.9\% vs 8\%). Growth differences in terms of height and weight were not significantly different between the two groups $(p>0.05)$. Severe intraventricular hemorrhage (IVH), hydrocephalus and invasive mechanical ventilation requirements negatively affected the growth in height and reaching the target height $(p<0.05)$.

Conclusion: The moderate-late and early preterm infants had similar growth features in terms of weight, height, and target height when evaluated at 42 months of age.

Keywords: Moderate-late preterms, early preterms, growth, target height, early childhood

Öz

Amaç: Çalışmamızın amacı çocukluk çağında orta-geç ve erken prematürelerin fiziksel büyüme özelliklerini karşılaştırmak ve büyümeyi etkileyen perinatal ve postnatal risk faktörlerini değerlendirmek idi. Yöntem: Ünitemizde takip edilen orta-geç ve erken preterm bebeklerin kilo, boy ve hedef boy gibi somatik büyüme özellikleri ortalama 42 ayda değerlendirildi. Intrauterin büyüme özelliklerinin mevcut büyüme üzerindeki etkileri ile birlikte perinatal ve erken neonatal problemlerin etkileri de araştırıldı.

Bulgular: 232 orta-geç preterm bebek (Grup I) (ortalama gestasyonel yaş: $34.9 \pm 1.2$ hafta) ve 112 erken

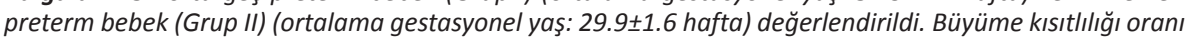
Grup I ve Grup II'de sırasıyla \%2.6 ve \%6.3 idi. Hedef boya ulaşamama oranı Grup II'de yüksekti. (\%3.9 \& \%8). Her iki grup arasında boy ve kilo açısından büyüme farklılıkları istatistiksel olarak anlamlı değildi. Ağır intraventriküler hemoraji (IVH), hidrosefali ve invaziv mekanik ventilasyon gereksinimi boy uzamasını ve hedef boya ulaşmayı olumsuz etkilemekteydi.

Sonuç: Orta-geç ve erken pretermler ortalama 42 ayda değerlendirildiğinde kilo, boy ve hedef boy açısından benzer büyüme özelliklerine sahipti.

Anahtar kelimeler: Orta-geç preterm bebekler, erken preterm bebekler, büyüme, hedef boy, erken çocukluk dönemi

$\begin{array}{r}\text { Received: } 08.06 .2020 \\ \text { Accepted: } 13.03 .2021 \\ \text { First Publication: } 20.09 .2021 \\ \hline\end{array}$

Cite as: Akar S, Kavuncuoglu S, Akın MA, Aldemir $E$, Demirhan A. Somatic growth features of moderate-late and early preterm infants at early childhood. İzmir Dr. Behçet Uz Çocuk Hast. Dergisi. 2021;11(3):226-32.

Selahattin Akar Bakırköy Kadın Doğum ve Çocuk Hastalıkları Eğitim ve Araştırma Hastanesi, Yenidoğan Yoğun Bakım Ünitesi, İstanbul, Türkiye

selahattinakar2001@yahoo.com ORCID: 0000-0001-5915-8652

S. Kavuncuoğlu 0000-0002-6323-8994

M.A. Akın 0000-0001-6102-2703

E. Aldemir 0000-0001-6141-7940

A. Demirhan 0000-0003-3107-4873 Bakırköy Kadın Doğum ve Çocuk Hastalıkları Eğitim ve Araştırma Hastanesi, Yenidoğan Yoğun Bakım Ünitesi, istanbul, Türkiye 


\section{INTRODUCTION}

Prematurity is the most important issue in the current neonatal care system and remains a longterm health and neurodevelopmental problem. An increasing proportion of preterm newborns, especially moderate-late preterms $\left(32^{0 / 7}-36^{6 / 7}\right.$ weeks), have higher rates of neonatal unit admissions compared to full-term newborns. The major problem for this risk group is a high mortality rate in the short-term and neurodevelopmental and somatic growth retardation in the long-term.

Preterm newborns are not a homogeneous group. Moderate (delivery between $32^{0 / 7}$ and $33^{6 / 7}$ weeks) and late preterm babies (delivery between $34^{0 / 7}$ and $36^{6 / 7}$ weeks) are associated with adverse short-term and long-term outcomes ${ }^{(1-3)}$. Moderate-late preterms babies constitute $4.4 \%-10 \%$ of all deliveries ${ }^{(4)}$. The groups that faces more risks in both aspects include early preterms (born prior to 32 weeks), including very early preterms (delivery between 28 and 32 weeks) and extremely early preterms (delivery before 28 weeks). Most early preterms also have a very lowbirth-weight (VLBW). Compared to early preterms, moderate-late preterm infants are at a lower risk of numerous medical problems. However, somatic growth retardation, neurodevelopmental retardation and behavioral disorders are observed in the longterm follow-up of moderate-late preterms ${ }^{(5-7)}$. Some studies have focused on the somatic growth in early preterms and their neurodevelopment (8-11). Moreover, there are a lot of studies on the neurodevelopment of late-moderate preterms ${ }^{(12)}$. However, as far as we know, there are no study in the literature that compare the long-term somatic growth between moderate-late preterms and early preterms in our country.

In this study, we aimed to compare the somatic growth features of moderate-late preterms and early preterms, where the adjusted age was not used, and instead, a chronological age of 42 months was used. Additionally, the risk factors, including the early and late neonatal morbidities that affect their growth features were compared between both groups.

\section{MATERIAL and METHOD}

This study was conducted on preterm infants who were born as moderate-late preterms (range of gestational age was $32^{0 / 7}-36^{6 / 7}$ weeks), according to the Ballard score ${ }^{(13)}$, and early preterms (born prior to 32 weeks). The moderate-late preterms were included in Group I and the early preterms in Group II.

All subjects were born in our hospital and discharged from our tertiary level neonatal intensive carrier unit (NICU). All the discharged infants continued to have follow-ups in our out-patient clinics. Both the groups' growth features were evaluated at a mean age of 42 months.

The patients' data including prenatal risk factors and early neonatal morbidities were obtained from the NICU records in our hospital. The intrauterine growth properties were evaluated by the intrauterine growth curve for Turkish children ${ }^{(14)}$. A percentile value of $10-90^{\text {th }}$ percentile on the growth chart was considered Appropriate for Gestational Age (AGA) and a percentile value below the $10^{\text {th }}$ percentile was considered Small for Gestational Age (SGA). The perinatal risk factors that have influence on growth in both groups were identified as maternal history of smoking, premature rupture of membranes (PROM), receiving antenatal steroids, newborns' history of resuscitation in the delivery room, and a low APGAR score (at the $5^{\text {th }}$ minute $<6$ ). Early neonatal morbidities during NICU stay admission, including respiratory distress syndrome (RDS), invasive mechanical ventilation, early and/late onset sepsis, hypoglycemia, anemia, meningitis, bronchopulmonary dysplasia (BPD), seizure, surgical necrotizing enterocolitis with perforation (advanced stage NEC), moderate-severe intraventricular hemorrhage (grade III and IV IVH) with/without hydrocephalus and retinopathy of prematurity (ROP) were recorded.

A written informed consent was taken from all parents of the participants' and approval for the study was granted by the local ethics committee. (Bakırköy Women's and Children's Diseases Education and Research Hospital Ethics Committee, Decision no:25/06/09/270).

The infants' data of growth features were 
obtained from the outpatient follow-up clinic records. A Harpenden Stadiometer device was used to measure the subjects' height. The subjects were weighed as naked on a digital infant scale. The actual height $(\mathrm{cm})$ and weight $(\mathrm{kg})$ measurements of the subjects were recorded and marked on the percentile curves for the Turkish children ${ }^{(15)}$. During this process, the adjusted age calculation was not made, because all the subjects were older than 36 months. To predict the final height of the subjects and the familial effects on it, we used the target height formula prepared for the Turkish population (15-18). The subjects who had congenital anomalies, died after discharge, and/or did not continue follow-up regularly were not included in the study.

\section{Statistical Analysis}

Statistical analyses were made with the SPSS (Statistical Program in Social Sciences) version 15.0 package program. To test the normal distribution of variables, visual (histogram and probability graphics) and analytic methods (Kolmogorov-Smirov/ShapiroWilk tests) were used. Clinical characteristics of the infants are described by mean values and standard deviation, or rates and percentage. Univariate statistical analysis was performed using the Student t test for parametric continuous variables, MannWhitney $U$ test test for nonparametric continuous variables, and Fisher exact test or Chi-square test for categorical variables. A $p$-value $<0.05$ was considered statistically significant.

\section{RESULTS}

Group I and Group II consisted of 232 and 112 infants, respectively. The gestational age was 34.9 \pm 1.2 (range 32-36) weeks in Group I and 29.9 \pm 1.6 (range 26-31.6) weeks in Group II. The chronological ages of the groups were $42.8 \pm 1.6$ (range 37-45) months and $42.9 \pm 2.2$ (range 37-46) months. The demographic data of the subjects, including gender, intrauterine growth properties, birth weight, actual height and weight, target height, and their parents' height are summarized in Table 1.

Among the perinatal risk factors, receiving antenatal steroid, being underwent resuscitation, and low APGAR scores were significantly high in Group II, in accordance with our expectation. Furthermore, early neonatal morbidities, such as anemia, RDS, invasive mechanical ventilation support requirement, sepsis, hypoglycemia, meningitis, seizure, surgical NEC, moderate-severe IVH, BPD, and ROP were significantly higher in Group II, as expected (Table 2).

The height growth remained below the 3rd percentile in $6(2.6 \%)$ of the Group I subjects and in $7(6.3 \%)$ of the Group II subjects. However, the difference between groups was not statistically significant (Table 3). Nine (3.9\%) of the late preterm infants and 9 (8\%) of the early preterm infants could not achieve the target height percentile, but the difference was not statistically significant (Table 4). Additionally, the effects of gender and intrauterine

Table 1. Demographic data of the subjects in both groups.

\begin{tabular}{|c|c|c|c|}
\hline & $\begin{array}{l}\text { Group I } \\
(n=232)\end{array}$ & $\begin{array}{l}\text { Group II } \\
(n=112)\end{array}$ & $\mathbf{p}$ \\
\hline Female $[\mathrm{n}(\%)]$ & $120(51.7 \%)$ & $64(57.1 \%)$ & 0.32 \\
\hline Male $[\mathrm{n}(\%)]$ & $112(48.3 \%)$ & $48(42.9 \%)$ & 0.12 \\
\hline Gestational Age (w) [mean \pm SD (range)] & $34.9 \pm 1.2(32-36)$ & $29.9 \pm 1.6(26-31.6)$ & 0.56 \\
\hline Birth Weight (g) [mean (range)] & $1826.3 \pm 373.5(840-3550)$ & $1191.8 \pm 264.5(740-1980)$ & 0.02 \\
\hline AGA $[n(\%)]$ & $194(83.6 \%)$ & $83(74.1 \%)$ & 0.63 \\
\hline SGA $[n(\%)]$ & $38(16.4 \%)$ & $29(25.9 \%)$ & 0.42 \\
\hline Chronological Age (months) [mean $\pm S D$ (range)] & $42.8 \pm 1.6(37-45)$ & $42.9 \pm 2.2(37-46)$ & 0.74 \\
\hline Current Height $(\mathrm{cm})[$ mean $\pm S D$ (range)] & $100 \pm 3.5(92-106)$ & $97.7 \pm 5.9(85-106)$ & 0.45 \\
\hline Current Weight (kg) [mean \pm SD (range)] & $16.5 \pm 1.4(13-19)$ & $15.1 \pm 2.7(10-19)$ & 0.55 \\
\hline Maternal Height (cm) [mean \pm SD (range)] & $160 \pm 4.7(149-175)$ & $160.8 \pm 4.7(149-176)$ & 0.76 \\
\hline Paternal Height $(\mathrm{cm})[$ mean \pm SD (range)] & $175.5 \pm 5.3(155-192)$ & $176.2 \pm 5.6(160-192)$ & 0.81 \\
\hline Target Height $(\mathrm{cm})[$ mean \pm SD (range)] & $168.4 \pm 7.3(148.5-187)$ & $167.6 \pm 7.4(151-186.5)$ & 0.86 \\
\hline
\end{tabular}

AGA: Appropriate for Gestational Age, SGA: Small for Gestational Age. 
Table 2. Distribution of the neonatal morbidities of the subjects.

\begin{tabular}{|c|c|c|c|}
\hline & $\begin{array}{c}\text { Group I }(n=232) \\
n(\%)\end{array}$ & $\begin{array}{c}\text { Group II ( } n=112) \\
n(\%)\end{array}$ & $p$ value \\
\hline Hyperbilirubinemia & $46(19.8)$ & $29(25.9)$ & $>0.05$ \\
\hline Anemia & $72(31)$ & $63(56.3)$ & $<0.05$ \\
\hline RDS & $33(14.2)$ & $33(29.5)$ & $<0.05$ \\
\hline Sepsis & $41(17.6)$ & $28(25)$ & $<0.05$ \\
\hline Hypoglycemia & $29(12.5)$ & $21(18.8)$ & $<0.05$ \\
\hline Meningitis & $19(8.2)$ & $16(14.3)$ & $<0.05$ \\
\hline Post hemorrhagic hydrocephalus & $2(0.9)$ & $4(3.6)$ & $<0.05$ \\
\hline BPD & $6(2.6)$ & $13(11.6)$ & $<0.05$ \\
\hline Convulsion & $9(3.9)$ & $11(9.8)$ & $<0.05$ \\
\hline >Stage III ICH & $4(1.7)$ & $7(6.3)$ & $<0.05$ \\
\hline >Stage III NEC & $15(6.5)$ & $12(10.7)$ & $<0.05$ \\
\hline$>$ Stage III ROP & $2(0.9)$ & $7(6.3)$ & $<0.05$ \\
\hline
\end{tabular}

RDS: Respiratory distress syndrome BPD: Bronchopulmonary dysplasia, NEC: Necrotizing enterocolitis, ROP: Retinopathy of prematurity, ICH: Intracranial Hemorrhage.

Table 3. Comparison of the somatic growth of the subjects according to the percentile curve.

\begin{tabular}{|c|c|c|c|c|c|}
\hline & \multicolumn{2}{|c|}{$\begin{array}{l}\text { Group I } \\
(n=232)\end{array}$} & \multicolumn{2}{|c|}{$\begin{array}{l}\text { Group II } \\
(n=112)\end{array}$} & \multirow[b]{2}{*}{$p$ value } \\
\hline & $\begin{array}{c}\leq 3^{\text {rd }} \text { Percentile } \\
n(\%)\end{array}$ & $\begin{array}{c}>3^{\text {rd }} \text { Percentile } \\
\text { n (\%) }\end{array}$ & $\begin{array}{c}\leq 3^{\text {rd }} \text { Percentile } \\
n(\%)\end{array}$ & $\begin{array}{c}>3^{\text {rd }} \text { Percentile } \\
\text { n (\%) }\end{array}$ & \\
\hline Height & $6(2.6)$ & $226(97.4)$ & $7(6.3)$ & 105 (93.8) & $>0.05$ \\
\hline Weight & $13(5.6)$ & 219 (94.4) & $11(9.8)$ & $101(90.2)$ & $>0.05$ \\
\hline
\end{tabular}

growth features on the target height were not significant in both groups (Table 4).

The effects of SGA, AGA and gender on weight and height at 42 months were similar between the groups. There was no significant difference between the groups in terms of the relationship between the

Table 4. The effect of intrauterine growth characteristics and gender on growth in height and target height achievement in both groups.

\begin{tabular}{lccc}
\hline & $\begin{array}{c}\text { Group I } \\
(\mathbf{n = 2 3 2 )} \\
\text { Cases That Could Not } \\
\text { Achieve the Target } \\
\text { Percentile } \\
\mathbf{n ( \% )}\end{array}$ & $\begin{array}{c}\text { Group II } \\
(\mathbf{n = 1 1 2 )} \\
\text { Cases That Could Not } \\
\text { Achieve the Target } \\
\text { Percentile } \\
\mathbf{n ~ ( \% ) ~}\end{array}$ & p value \\
\hline Height & $9(3.9)$ & $9(8)$ & $>0.05$ \\
Female & $5(2.2)$ & $5(4.5)$ & $>0.05$ \\
Male & $4(1.7)$ & $4(3.6)$ & $>0.05$ \\
AGA & $3(1.3)$ & $4(3.6)$ & $>0.05$ \\
SGA & $6(2.6)$ & $5(4.5)$ & $>0.05$ \\
\hline
\end{tabular}

AGA: Appropriate for Gestational Age, SGA: Small for Gestational Age. diagnosis of RDS, BPD, sepsis and hypoglycemia and reaching the target height (Tablo 5). However, the

Table 5. The effects of the main neonatal morbidities on the target height in both groups.

\begin{tabular}{|c|c|c|c|}
\hline & 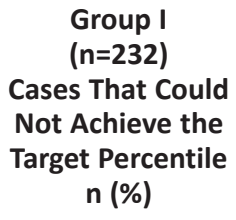 & 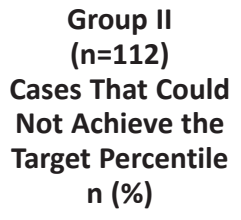 & p value \\
\hline RDS & $5(2.2)$ & $8(7.1)$ & $>0.05$ \\
\hline BPD & $4(1.7)$ & $7(6.3)$ & $>0.05$ \\
\hline Sepsis & $3(1.3)$ & $5(4.5)$ & $>0.05$ \\
\hline >Stage III NEC & $3(1.3)$ & $4(3.5)$ & $>0.05$ \\
\hline Hypoglycemia & $4(1.7)$ & $8(3.5)$ & $>0.05$ \\
\hline$\geq$ Stage III ICH & $3(1.3)$ & $7(6.3)$ & $<0.05$ \\
\hline Hydrocephalus & $2(0.9)$ & $3(3.6)$ & $<0.05$ \\
\hline Follow-up in ICU & $5(2.2)$ & $8(7.1)$ & $>0.05$ \\
\hline Mechanical & $3(1.3)$ & $9(8)$ & $<0.05$ \\
\hline \multicolumn{4}{|l|}{ Ventilatory } \\
\hline Support & & & \\
\hline
\end{tabular}

RDS: Respiratory Distress Syndrome, BPD: Bronchopulmonary Dysplasia, NEC: Necrotizing Enterocolitis, ICH: Intracranial Hemorrhage, ICU: Intensive Care Unit. 
subjects who could not achieve the target height had a significantly higher rate of invasive ventilation, and moderate to severe IVH and hydrocephalus in Group II compared to Group I (Table 5). In addition, the need for mechanical ventilation, and the frequency of IVH, BPD and hydrocephalus were higher in the infants with a height and a weight below the 3th percentile at 42 months. When growth in weight was evaluated, $13(5.6 \%)$ of the late preterm infants and $11(9.8 \%)$ of the early preterm infants were found to be below the 3rd percentile; however, the difference between the groups was not significant (Table 3).

\section{DISCUSSION}

To the best of our knowledge, this is the first study from our country that investigates and compares the growth characteristics of infants who were older than 3 years and those who were born as early and moderate-late preterms and also prenatal, postnatal and genetic factors affecting on them. According to our results, the growth features, including weight, height, and achieving target height were similar between the late and early preterms at postnatal 42 months of age. Moderate-severe IVH, hydrocephalus and invasive mechanical ventilation support had negative effects on the target height in both groups.

There are many studies that support the negative effects of early neonatal morbidities on the growth characteristics of preterms who have perinatal risks, especially when they were assessed according to their corrected age. The effects of intrauterine growth retardation on postnatal growth has been emphasized in some studies. On the contrary, there are some authors who advocate that intrauterine growth characteristics do not affect the growth features of preterms. They suggest that preterms achieve the normal growth percentile up to the age of two years if there are no perinatal complications and no severe congenital anomalies and if optimal postnatal care was given ${ }^{(8,19)}$. Since the growth properties of preterms, especially after the age of 3 years, are shaped by the effects of genetic and environmental factors, the effects of early neonatal problems, gender, and being AGA and SGA are limited. In support of this knowledge, the present study revealed that gender and intrauterine growth features do not affect all the growth features, including those of both moderate-late and early preterms when they are 42 months old.

According to the studies covered in the earlier period on first and second years of corrected age ${ }^{(20)}$, the growth properties of preterms and term/late preterm newborns are different ${ }^{(21-23)}$. Koc et al. ${ }^{(11)}$ reported growth retardation as 6\% in height and $7 \%$ in weight in school-age premature children. Severe neurodevelopmental problems were described by $80 \%$ of the cases with growth retardation in height, while there was no such a relationship in retardation in weight. In a study by Sütçüoglu et al. ${ }^{(10)}$, growth retardation was reported as $20.5-27.8 \%$ in height and $32.8 \%-24.6 \%$ in weight in VLBW premature infants at $18-20$ months. In the same study, neurodevelopmental retardation was stated to be the most common cause of retardation in height. Toome $L$ et al. ${ }^{(27)}$ compared premature infants born before the $32^{\text {th }}$ week of gestation with 2 years old term infants and emphasized that somatic growth was a statistically significant problem in premature infants. In a study from our country by Yesinel $S$ et al. (9), in which adjusted age was used, the results showed that the intrauterine growth characteristics, being SGA or AGA, and gender did not affect the growth properties of VLBW preterms at the mean age of $\mathbf{3 6}$ months. Their results showed that invasive mechanical ventilation support, presence of chronic diseases, severeIVH, posthemorrhagichydrocephalus, and lack of breastfeeding negatively affected the growth in height and target height achievement as well. The effect of gender on preterms' growth features have also been studied in the literature. A study that focused on the growth features of SGA babies showed that male preterms had a higher rate of failing to catch-up on growth (for both weight and height) postnatally up to the age of 4 years (boys $11 \%$, girls $5 \%)^{(21)}$. Some of the factors mentioned above, especially severe IVH, hydrocephalus, and invasivemechanicalventilation support requirements, have negative effects on the growth in height and 
achievement of target height in preterms. The effect of gender on growth was not observed in both groups in our study. Problems with reaching the target height in very small premature babies are more common because they are more exposed to such problems related to prematurity. One of the important problems that affect growth is the presence of chronic disease, especially BPD and hydrocephalus. They cause chronic hypoxia, recurrent hospitalizations and surgery, infections, nutritional problems, etc. Finally, growth is affected negatively ${ }^{(24,25)}$. The growth retardation rate can reach to $10 \%$ in cases with BPD and hydrocephalus ${ }^{(9,26)}$. In our study, BPD did not affect the growth in both groups, but an advanced stage IVH and hydrocephalus negatively affected the growth in height in both the groups.

One of the most important factors that affect physical growth is inheritance. A child who grows up normally reaches the percentile appropriate for his/ her genetic potential after 6-12 months and the growth in height after 2-3 years and correlates with parental height. Therefore, it is important to determine the percentile of the child's growth in height and its compatibility with the target height to calculate the final height ${ }^{(16-18)}$. Our results showed that moderate-late and early preterms have similar growth features in terms of height catch-up and also achievement of the target height. The findings of our study suggest that growth after the age of 2-3 years shows correlation to genetic and environmental factors, as mentioned before. Severe IVH, hydrocephalus and mechanical ventilation support requirements have a negative effect on the growth in height and achievement of target height in preterms of both groups.

We can conclude that moderate-late preterms and early preterms have similar growth features, including weight, height, and target height, when they reach the early childhood period. The prenatal risk factors, including intrauterine growth features and postnatal morbidities, especially IVH and/or hydrocephalus, and invasive mechanical ventilation, affect the growth features of preterms when they are evaluated at the early childhood period.
Ethics Committee Approval: Ethics Committee approval of Bakırköy Gynecology and Pediatrics Training and Research Hospital was obtained (25.06.2009/270).

Conflict of Interest: None.

Funding: None.

Informed Consent: Written informed consents were obtained from the parents.

\section{REFERENCES}

1. Raju TN, Higgins RD, Stark AR, Leveno KJ. Optimizing care and outcome for late-preterm (near-term) infants: a summary of the workshop sponsored by the National Institute of Child Health and Human Development. Pediatrics. 2006;118(3):1207-14.

https://doi.org/10.1542/peds.2006-0018

2. Boyle EM, Johnson S, Manktelow B, et al. Neonatal outcomes and delivery of care for infants born late preterm or moderately preterm: a prospective population-based study. Arch Dis Child Fetal Neonatal Ed. 2015;100(6):F479-F85. https://doi.org/10.1136/archdischild-2014-307347

3. Kalyoncu $O$, Aygün $C$, Cetinoğlu $E$, Küçüködük $S$. Neonatal morbidity and mortality of late-preterm babies. J Matern Fetal Neonatal Med. 2010;23(7):607-12.

https://doi.org/10.3109/14767050903229622

4. Ananth CV, Friedman AM, Gyamfi-Bannerman C. Epidemiology of moderate preterm, late preterm and early term delivery. Clin Perinatol. 2013;40(4):601-10. https://doi.org/10.1016/j.clp.2013.07.001

5. de Jong $M$, Verhoeven $M$, Lasham CA, Meijssen CB, van Baar AL. Behaviour and development in 24-month-old moderately preterm toddlers. Arch Dis Child. 2015;100(6):548-53. https://doi.org/10.1136/archdischild-2014-307016

6. Johnson S, Evans TA, Draper ES, et al. Neurodevelopmental outcomes following late and moderate prematurity: a population-based cohort study. Arch Dis Child Fetal Neonatal Ed. 2015;100(4):F301-F8. https://doi.org/10.1136/archdischild-2014-307684

7. Woythaler MA, McCormick MC, Smith VC. Late preterm infants have worse 24-month neurodevelopmental outcomes than term infants. Pediatrics. 2011;127(3):e622-e9. https://doi.org/10.1542/peds.2009-3598

8. Niklasson A, Engstrom E, Hard AL, Wikland KA, Hellstrom A. Growth in very preterm children: a longitudinal study. Pediatr Res. 2003;54(6):899-905. https://doi.org/10.1203/01.PDR.0000091287.38691.EF

9. Yeşinel S, Aldemir EY, Kavuncuoğlu S, Yeşinel S, Yıldız H. Evaluation of growth in very Low birth weight preterm babies. Turk Pediatri Ars. 2014;49(4):289-98. Published 2014 Dec 1. https://doi.org/10.5152/tpa.2014.1989

10. Sütçüoğlu S, Dikerler A, Halıcıoğlu $O$, Akkaya M, Öztürk $C$, Akman S, Özer E. Neurodevelopmental follow-up results in very low birth weight premature infants and influential factors. Behcet Uz Cocuk Hast Derg. 2012;2(2):94-101. https://doi.org/10.5222/buchd.2012.094

11. Koç Ö, Kavuncuoğlu S, Ramoğlu MG, Aldemir E, Aktalay A, Eras Z. School Performance and Neurodevelopment of Very Low Birth Weight Preterm Infants: First Report From Turkey. 
J Child Neurol. 2016;31(2):170-6. https://doi.org/10.1177/0883073815587028

12. de Jong $M$, Verhoeven $M$, van Baar AL. School outcome, cognitive functioning, and behaviour problems in moderate and late preterm children and adults: a review. Semin Fetal Neonatal Med. 2012;17(3):163-9. https://doi.org/10.1016/j.siny.2012.02.003

13. Ballard JL, Khoury JC, Wedig K, Wang L, Eilers-Walsman BL, Lipp R. New Ballard Score, expanded to include extremely premature infants. J Pediatr. 1991;119(3):417-23. https://doi.org/10.1016/S0022-3476(05)82056-6

14. Ovali F. Intrauterine growth curves for Turkish infants born between 25 and 42 weeks of gestation. J Trop Pediatr. 2003;49(6):381-3. https://doi.org/10.1093/tropej/49.6.381

15. Gökçay G, Furman A, Neyzi O. Updated growth curves for Turkish children aged 15 days to 60 months. Child Care Health Dev. 2008;34(4):454-63. https://doi.org/10.1111/j.1365-2214.2008.00813.x

16. Bundak R, Neyzi O. Büyüme-Gelişme in Neyzi $O$, Ertuğrul $T$ (eds). Pediatri İstanbul Nobel Tıp Kitabevi; 2010.p. 89-113.

17. Lifshitz F, Cervantes CD. Short stature. In Lifshitz F (eds) Pediatric Endocrinology ( $3^{\text {rd }}$ ed) New York Marcel Deckel Inc; 1996.p.1-18.

18. Rosenfeld RG and Cohen P. Disorders of growth hormone / insulin like growth factor secretion and action in Sperling MA (edit). Pediatric Endocrinology (2nd ed) Philadelphia,Saunders Co; 2002.p.211-88.

19. Tenovuo A, Kero P, Piekkala $P$, Korvenranta $H$, Sillanpää $M$, Erkkola R. Growth of 519 small for gestational age infants during the first two years of life. Acta Paediatr Scand. 1987;76(4):636-46.

https://doi.org/10.1111/j.1651-2227.1987.tb10534.x

20. Casey PH, Kraemer HC, Bernbaum J, et al. Growth patterns of low birth weight preterm infants: a longitudinal analysis of a large, varied sample. J Pediatr. 1990;117(2 Pt 1):298-307. https://doi.org/10.1016/S0022-3476(05)80551-7

21. Albertsson-Wikland $K$, Wennergren $G$, Wennergren $M$, Vilbergsson G, Rosberg S. Longitudinal follow-up of growth in children born small for gestational age. Acta Paediatr. 1993;82(5):438-43.

https://doi.org/10.1111/j.1651-2227.1993.tb12718.x

22. Kavuncuoğlu S, Hanedan S, Hatipoğlu N, Aktay N, Öztürk S. Catch-up growth features of premature infants and effects of different patterns of nutrition on growth. Turk Pediatri Ars. 2001;36:26-31.

23. Hack M, Schluchter M, Cartar L, Rahman M, Cuttler L, Borawski E. Growth of very low birth weight infants to age 20 years. Pediatrics. 2003;112(1 Pt 1):e30-e8. https://doi.org/10.1542/peds.112.1.e30

24. McGowan JE, Alderdice FA, Doran J, et al. Impact of neonatal intensive care on late preterm infants: developmental outcomes at 3 years. Pediatrics. 2012;130(5):e1105-e12. https://doi.org/10.1542/peds.2012-0745

25. Shrivastava A, Lyon A, Mclntosh N. The effect of dexamethasone on growth, mineral balance and bone mineralisation in preterm infants with chronic lung disease. Eur J Pediatr. 2000;159(5):380-4. https://doi.org/10.1007/s004310051291

26. Kavuncuoğlu S, Aldemir E, Altuncu E, Arduç A, Alpaslan S, Arslan G, et al. Assessment of the patients with bronchopulmonary dysplasia in terms of somatic growth, pulmonary problems and neurodevelopmental features on long-term follow-up .Turk Pediatri Ars. 2008;43(1):17-23.

27. Toome L, Varendi $H$, Männamaa $M$, Vals MA, Tänavsuu $T$, Kolk A. Follow-up study of 2-year-olds born at very low gestational age in Estonia. Acta Paediatr. 2013;102(3):300-7. https://doi.org/10.1111/apa.12091 